\title{
IN HOUSE TRAINING PERUMUSAN VISI MISI RUANGAN PERAWATAN PERINATAL RSUD PRINGSEWU
}

\author{
Diny Vellyana \\ Keperawatan, STIKes Muhammadiyah Pringsewu Lampung \\ email: vellyanadiny@yahoo.com
}

\begin{abstract}
abstrak
Penentuan arah strategi dimulai dengan penentuan dan pengakuan identitas yang terdiri dari perumusan visi dan misi, keyakinan dasar, nilai-nilai dasar dan tujuan organisasi, mengingat bahwa dalam garis manajerial rumah sakit terdiri dari berbagai jenis ruang perawatan yang berarti bahwa Setiap kamar memiliki karakteristik layanan yang berbeda, sehingga harus memiliki tujuan khusus tersendiri. Tujuan dari kegiatan pelatihan in-house adalah perumusan visi dan misi ruangan, yaitu untuk meningkatkan pemahaman pemangku kepentingan dalam perumusan Visi dan Misi ruang perawatan Perinatal di Rumah Sakit Umum Pringsewu. Metode pelaksanaannya dimulai dari perencanaan, pelaksanaan dan evaluasi perumusan visi dan misi hingga kepala ruang Perinatal, koordinator ruang, praktisi perawat dan petugas kesehatan serta semua jalur kesehatan yang ada di Ruang Perinatal di Rumah Sakit Umum Pringsewu. Hasil dari kegiatan tersebut mampu menjadikan visi dan misi ruangan dengan baik. Keberadaan kegiatan ini mampu memberikan contoh ke ruangan lain untuk menciptakan visi dan misi secara mandiri.
\end{abstract}

Kata kunci: in house training, visi dan misi, keperawatan

\begin{abstract}
Determination of strategy direction begins with the determination and recognition of identity which consists of the formulation of a vision and mission, basic beliefs, basic values and organizational goals, considering that in the managerial line the hospital consists of various types of treatment rooms which means that each room has service characteristics that different, so it must have its own special purpose. The purpose of the in house training activities is the formulation of the room's vision and mission, namely to increase the understanding of stakeholders in the formulation of the Vision and Mission of the Perinatal care room at the Pringsewu General Hospital. The method of implementation is starting from planning, implementing and evaluating the formulation of the vision and mission to the head of the Perinatal room, the room coordinator, nurse practitioners and health workers as well as all health lines that are in the Perinatal Room of the Pringsewu General Hospital. The results of the activity are able to make the vision and mission of the room well. The existence of this activity is able to provide an example to another room to create a vision and mission independently.
\end{abstract}

Keywords: in house training;vision and mission;nursing

\section{PENDAHULUAN}

Ketidaktersedianya arah strategi yang jelas dapat menjadi sebuah kelemahan sebuah pelayanan kesehatan karena kondisi tersebut menempatkan pada posisi persaingan yang kurang baik, kesenjangan kemampuan manajerial, lini produk yang sempit dan akhirnya citra yang kurang baik. Penentuan arah strategi diawali dari penentuan dan pengenalan jati diri yaitu terdiri dari perumusan visi misi, keyakinan dasar,nilai dasar dan tujuan organisasi, mengingat di dalam lini manajerial rumah sakit terdiri dari berbagai jenis ruang perawatan yang berarti bahwa masing - masing ruangan memiliki karakteristik pelayanan yang berbeda, sehingga harus memiliki tujuan khusus serta tersendiri.

Hal tersebut menunjukkan bahwa pentingnya ada sebuah strategi yang dituangkan dalam jati diri visi misi ruangan 
untuk mencapai keberlangsungan dan kualitas sistem pelayanan,yang menurut Fred $\mathrm{R}$. David (2004) strategi adalah cara untuk mencapai tujuan - tujuan masa panjang. RSUD Pringsewu yang sedang menjalani proses perkembangan sudah memiliki Visi dan Misi Rumah Sakit secara jelas, namun masih ada ruangan perawatan yang belum memiliki Visi Misi ruangan, salah satunya adalah ruang perinatal.

Mengingat bahwa setiap ruangan memiliki karakteristik dan tujuan yang berbeda maka adanya sebuah Visi dan Misi di ruang perwatan perlu dirumuskan. Oleh karena itu, STIKes Muhammadiyah Pringsewu sebagai perguruan tinggi yang berlatar belakang kesehatan peduli dengan masalah-masalah kesehatan beserta manajemen pada ruang lingkup kesehatan yang ada dilingkungannya, khususnya di RSUD yang ada di Kabupaten Pringsewu bertujuan untuk memberikan House Trainning Perumusan Visi dan Misi di Ruang Perinatal RSUD Pringsewu.

\section{MASALAH, TARGET DAN LUARAN}

RSUD Pringsewu yang sedang menjalani proses perkembangan sudah memiliki Visi dan Misi Rumah Sakit secara jelas, namun masih ada ruangan perawatan yang belum memiliki Visi Misi ruangan, salah satunya adalah ruang perinatal. Mengingat bahwa setiap ruangan memiliki karakteristik dan tujuan yang berbeda maka adanya sebuah Visi dan Misi di ruang perwatan perlu dirumuskan.

Sasaran yang dilakukan pada kegiatan ini adalah kepala ruangan Perinatal, Koordinator ruangan, perawat praktisi dan tenaga kesehatan serta semua lini kesehatan yang sedang berada diruangan Perinatal RSUD Pringsewu. Tujuan kegiatan ini yaitu eningkatkan pemahaman para stakeholder dalam perumusan Visi Misi ruang perawatan Perinatal RSUD Pringsewu

\section{METODE PELAKSANAAN}

Kegiatan pengabdian masyarakat dengan tema In House Training Perumusan Visi Misi Ruang Perinatal Di RSUD Pringsewu dilakukan melalui serangkaian kegiatan dalam pertemuan di ruang rawat inap Perinatal RSUD Pringsewu dengan diawali beberapa persiapan sampai pelaksanaan, kegiatan ini dihadiri oleh 18 peserta yang terdiri dari perawat praktiksi, tim manajerial ruangan Perinatal dan stakeholder RSUD Pringsewu. Kegiatan ini dilakukan pada hari Sabtu 22 July 2017 pukul 08.00 WIB s/d selesai.

\section{HASIL PEMBAHASAN}

Hasil dari pelaksanaan In House Training Perumusan Visi Misi Ruang Perinatal adalah sebagai berikut:

a. Visi

Menjadi ruang perawatan perinatalogi yang terpercaya melalui kualitas pelayanan prima

b. Misi

1) Mewujudkan pelayanan kesehatan neonatus yang berkualitas dan profesional

2) Meningkatkan status kesehatan BBLR melalui pelayanan komprehensif dan peralatan mutakhir

3) Mewujudkan ruang rawat inap yang memberikan kepuasan dan aman nyaman bagi klien

Visi dan Misi yang menjadi salah satu strategi manajemen rumah sakit memiliki makna sebagai berikut: a. Visi adalah apa yang akan dicapai di masa depan dantujuan masa depan. b. Misi adalah sebuah alasan/tujuan jangka panjang organisasi didirikan atau metode untuk mewujudkan Visi (Drucker F Peter dalam Hadna M.T tahun 2012).

Pembuatan visi dan misi dilakukan untuk menetapkan tujuan dan arahan perawat dalam menetapkan tujuan dalam perawatan secara maksimal yang mengacu pada tujuan yang telah disepakati.

\section{KESIMPULAN DAN SARAN}

Kesimpulan dari kegiatan In House Training Perumusan Visi Misi Ruang Perinatal Di RSUD Pringsewu yaitu meningkatnya pemahaman para stakeholder dalam perumusan Visi Misi ruang perawatan Perinatal RSUD Pringsewu. Beberapa saran dari kegiatan ini yaitu : 
a. Kepada pihak Manajerial RSUD Pringsewu untuk membuat Juknis dan SOP perumusan Visi Misi baik ruang perawatan maupun unit pelayanan berdasarkan format perumusan dan uji yang sudah dilampirkan

b. Membuat deadline pengumpulan Visi Misi ruang perawatan dan unit pelayanan untuk di sahkan oleh Direktur

c. Memberikan prasarana dan sarana yang memadai sesuai dengan kebutuhan pembuatan Visi Misi ruang perawatan dan unit pelayanan

d. Memberikan follow - up dan uji Visi Misi yang telah dirumuskan tim manajerial ruang perawatan dan unit pelayanan

Kegiatan ini sekiranya dapat dijadikan sebagai tambahan ilmu pengetahuan dan bagi instansi terkait sebagai bahan pertimbangan pengambilan kebijakan

\section{REFERENSI}

Penulisan naskah dan sitasi yang diacu dalam naskah ini disarankan menggunakan Harvard Style. 